\title{
Analysis of Relationship between Reflux Symptom Index and Psychiatric Problems
}

\author{
In-Jun Park, Jun-Myung Kang, Jae-Hyun Seo, Se-Hwan Hwang, \\ Ho-Young Youn, Ho-Jun Jin, Ha-Ram Kang, and Young-Hoon Joo \\ Department of Otolaryngology-Head and Neck Surgery, College of Medicine, The Catholic University of Korea, Seoul, Korea
}

\author{
역류증상지수와 정신과적 질환과의 상관관계 분석 \\ 박인준 · 강준명 · 서재현 · 황세환 · 윤호영 · 진호준 · 강하람 · 주영훈 \\ 가톨릭대학교 의과대학 이비인후과학교실
}

\author{
Received July 28, 2017 \\ Revised June 21, 2018 \\ Accepted August 1, 2018 \\ Address for correspondence \\ Young-Hoon Joo, MD, PhD \\ Department of Otolaryngology- \\ Head and Neck Surgery, \\ College of Medicine, \\ The Catholic University of Korea, \\ 327 Sosa-ro, Bucheon 14647, Korea \\ Tel $+82-32-304-7090$ \\ Fax $+82-32-340-2674$ \\ E-mail joodoct@catholic.ac.kr
}

Background and Objectives This study investigated the relationship between reflux symptom index (RSI) and psychiatric problems such as depression, somatization, and anxiety. Subjects and Method We prospectively analyzed 231 patients with symptoms with laryngopharyngeal reflux (LPR) using the RSI and the reflux finding score.

Results Seventy nine patients (34.2\%) were diagnosed with LPR. A significant correlation was detected between the RSI and depression (18.4 \pm 8.3 vs. $12.3 \pm 7.0, p<0.001)$, anxiety $(19.5 \pm$ 8.5 vs. $13.0 \pm 7.3, p<0.001)$, and somatization $(19.2 \pm 9.1$ vs. $13.6 \pm 7.5, p<0.001)$. A multivariate analysis confirmed a significant association between heartburn and depression [odds ratio (OR): $1.241,95 \%$ confidence interval (CI): $1.003-1.537, p=0.047$ ], choking and anxiety (OR: 1.747, 95\% CI: $1.297-2.352, p<0.001$ ), and choking and somatization (OR: $1.707,95 \% \mathrm{CI}$ : $1.248-2.336, p=0.001)$.

Conclusion Our preliminary results suggest that patients with high RSI may need to be carefully evaluated for psychiatric problems.

Korean J Otorhinolaryngol-Head Neck Surg 2018;61(12):692-6

Key Words Anxiety · Depression · Laryngopharyngeal reflux · Somatoform disorders.

\section{서 론}

인후두 역류질환(laryngopharyngeal reflux disease)은 상부 소화 호흡기계가 위산 역류에 노출되며 발생하는 것으 로, 속쓰림이 주된 증상인 위식도 역류질환과 차이가 있다고 보고되고 있다. 이런 인후두 역류질환은 이비인후과 외래 환 자의 약 4 10\%를 차지하는 것으로 알려져 있고, 최근 수년 간 점점 더 증가하는 추세에 있다. ${ }^{1,2)}$ 또한, 만성 후두염 증례와 더불어 쉽게 치료되지 않는 인후통 환자의 50 60\%가 인후두 역류질환과 연관이 있을 것으로 보고되고 있다.3)

This is an Open Access article distributed under the terms of the Creative Commons Attribution Non-Commercial License (https://creativecommons.org/licenses/by-nc/4.0) which permits unrestricted non-commercial use, distribution, and reproduction in any medium, provided the original work is properly cited.
인후두 역류질환에서는 위식도 역류질환에서 흔히 나타나 는 가슴쓰림, 산 역류, 오심, 구토, 연하곤란 등의 증상 없이 대개 목소리 변화, 만성적인 헛기침, 인후통, 인후두 이물감 등의 이비인후과적인 증상을 보인다. 이러한 증상을 나타내 는 환자들을 대상으로 한 후두경검사에서 특별한 이상 소견 이 관찰되지 않는 경우도 있으나, 일반적으로 인후두 역류질환 으로 판단하게 하는 후두 내시경 소견으로 후두 홍반(laryngeal erythema, hyperemia), 성대부종(vocal fold edema), 후 두실 폐쇄(ventricular obliteration), 후연합부 점막비후(posterior commissure hypertrophy), 가성 성대구(pseudosulcus vocalis) 등이 있다. ${ }^{1,4)}$ 이 중 후두 부종과 후연합부 점막비후 가 가장 흔하게 관찰되는 소견이다. ${ }^{5)}$

인후두 역류질환을 진단하기 위해서는 일차적으로 인후두 
역류질환의 증상 및 소견을 발견하는 것이 중요하다. 임상에 서 인후두 역류질환의 진단에 널리 쓰이는 대표적인 방법 중, Belafsky 등 6.7)이 제안한 역류증상지수(reflux symptom index) 와 역류소견점수(reflux finding score)가 있다. 역류증상지 수는 13점 이상, 역류소견점수는 7점 이상이 유의하게 증가 된 수치이며 이 자체가 인후두 역류질환의 진단 기준은 아니 지만 인후두 역류질환을 의심해봐야 할 수치이다. 이 중, 역 류증상지수는 “목청을 가다듬는다", "음식물을 삼키기 어렵 다", "목구멍에 이물감을 느낀다" 등 Belafsky 등 6,7)이 제안한 9가지 증상에 대하여 0 5점으로 평가하여 점수화한 것이다.

최근에는 역류증상지수와 역류소견점수를 바탕으로 양자 펌프 억제제(proton pump inhibitor)를 사용하여 인후두 역 류질환을 치료하는 경험적 치료법(empirical treatment)이 많이 사용되고 있다. 하지만 수개월간 양자펌프 억제제의 경 험적 치료법에도 불구하고 증상의 호전이 없는 경우가 많으 며 목에 이물감을 지속적으로 호소하는 환자들은 정신과적 인 요소들이 이러한 증상과 연관 있을 가능성을 생각해 볼 수 있다. ${ }^{48-10)}$ Carney 등 ${ }^{11)}$ 은 만성 기침 증상이 불안증 같은 정신과적 문제와 관계가 있다고 하였고, Färkkilä 등르는 인 후두부 이상감증 환자의 약 $25 \%$ 에서 정신장애가 있다고 하 였다. 또한 국내 연구들에서도, 인후두 역류질환의 한 증상 인 인후두부 이물감이 심인성 및 정신과적 문제와 연관 있 음을 밝힌 바 있으며, ${ }^{13,14)}$ 본 저자의 이전 연구에서도 인후두 역류질환의 임상 경과에 우울장애가 중요한 영향을 끼친다는 것을 보고한 바 있다. ${ }^{15}$

이에 본 연구에서는 인후두 역류질환 진단의 대표적 방법인 역류증상지수와 우울증을 비롯한 정신과적 질환들의 연관관 계를 평가해보고자 하였다.

\section{대상 및 방법}

2014년 4월부터 2015년 6월까지, 약 14개월간 역류로 인한 것으로 보이는 만성 후두 증상을 호소하여 본원 이비인후과 에 내원하였던 환자 231명을 대상으로 하였다. 포함 기준으 로는 20세 이상이며, 병력, 후두내시경 및 Stroboscope 검사, 역류증상지수와 역류소견점수를 통해 임상적으로 인후두 역 류질환이 진단된 환자로 하였다. 이비인후과 전문의가 후두 내시경 및 Stroboscope 검사를 시행하였으며, 역류소견점수 양식에 기입하였다. 역류소견점수는 8개 항목(성문하 부종, 후두실 폐쇄, 후두 발적, 성대 부종, 미만성 후두 부종, 후교 련 비후, 후두 육아종, 후두내 객담)에 따라 총점 0 26점으 로 평가하였으며(Table 1), 역류증상지수 설문조사는 인후두 역류질환의 9가지 다양한 증상에 대하여 각각 0 5점으로
Table 1. 역류소견점수(reflux finding score)

\begin{tabular}{|c|c|}
\hline \multirow[t]{2}{*}{ 성문하 부종(subglottic edema) } & $2=$ 유 \\
\hline & $0=$ =무 \\
\hline \multirow{2}{*}{ 후두실 폐쇄(ventricular obliteration) } & $2=$ 부분 \\
\hline & 4=전체 \\
\hline \multirow[t]{2}{*}{ 후두 발적(erythema/hyperemia) } & 2=피열연골부만 \\
\hline & 4=미만성 발적 \\
\hline \multirow[t]{3}{*}{ 성대 부종(vocal fold edema) } & $1=$ 경함 \\
\hline & 2 =중등도 \\
\hline & $4=$ 심함 \\
\hline \multirow[t]{4}{*}{ 미만성 후두 부종(diffuse laryngeal edema) } & $1=$ 경함 \\
\hline & $2=$ 중등도 \\
\hline & 3=심함 \\
\hline & 4=폐색 \\
\hline \multirow[t]{4}{*}{ 후교련 비후(posterior commissure hypertrophy) } & $1=$ 경함 \\
\hline & $2=$ 중등도 \\
\hline & $3=$ 심함 \\
\hline & $4=$ 폐색 \\
\hline \multirow[t]{2}{*}{ 후두 육아종(granuloma/granulation tissue) } & $2=$ 유 \\
\hline & $0=$ 무 \\
\hline \multirow[t]{2}{*}{ 후두내 객담(thick endolaryngeal mucus) } & $2=$ 유 \\
\hline & $0=$ 무 \\
\hline
\end{tabular}

총점 0 45점으로 평가하였다(Table 2). 인후두 역류질환은 역류소견점수 7점 이상이고 역류증상지수 13점 이상일 때 정의되었다. ${ }^{6,7)}$

인후두 역류질환 환자들에서 정신과적 질환들의 연관관 계를 보기 위하여 다음과 같은 평가척도를 사용하였다. 우울증 (depression)은 The Korean version of the Patient Health Questionnaire-9(PHQ-9), 신체화장애(somatization)는 PHQ15 , 불안증(anxiety)은 The 7-item Generalized Anxiety Disorder Scale(GAD-7) 지표를 사용하였다. 이전의 연구들을 바탕으로 우울증은 PHQ-9 5점 이상, 불안증은 GAD-7 5점 이상, 신체화장애는 PHQ-15 10점 이상으로 기준을 삼아 진 단하였다. ${ }^{16-18)}$ 통계처리는 SPSS for Windows(version 16.0; SPSS Inc., Chicago, IL, USA)를 사용하였고 통계학적 유의 성은 $p$-value $<0.05$ 이하를 기준으로 평가하였다. 본 연구 는 가톨릭대학교 의과대학 부천성모병원 임상시험심의위원 회의 승인(HC15RISI0108)을 받은 후 진행하였으며 모든 환 자들에게 동의서를 득하였다.

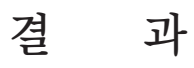

\section{환자군 특성}

총 231 명의 환자들이 본 연구에 참여하였으며 158 명(68.4\%) 
이 여성 환자였고, 평균 연령은 54.6세(20 78세)였다. 역류증 상지수 13점 이상은 131명(56.7\%)이였고, 역류소견점수 7점 이 상은 136명(58.9\%)였다. 역류증상지수 13점 이상이고 역류소 견점수 7점 이상인 환자는 총 79명으로, 인후두 역류질환의 이환율은 $34.2 \%$ 였다. 남자와 여자 성별 간 인후두 역류질환 이환율의 차이는 없었다(42.5\% vs. $30.4 \%, p=0.076)$.

우울증(PHQ-9), 신체화장애(PHQ-15), 불안증(GAD-7) 각

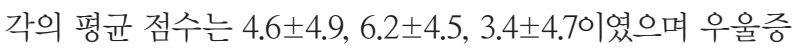
환자에게서 인후두 역류질환이 높게 관찰되었다(45.6\% Vs. $27.0 \%, p=0.004)$.

\section{역류증상지수와 우울증, 신체화장애, 불안증과의 관계}

역류증상지수 13점 이상이고 역류소견점수 7점 이상인 인후 두 역류질환 환자에서 우울증 $(5.6 \pm 5.3$ vs. $4.0 \pm 4.6, p=0.017)$ 과 불안증 $(4.3 \pm 4.9$ vs. $3.0 \pm 4.5, p=0.041)$ 에서 의미 있는 상관
관계가 관찰되었다.

9개의 평가항목 점수를 더한 역류증상지수는 우울증, 불안 증, 신체화장애와 단변량 분석을 해보았을 때, 모두 통계학적 으로 의미 있는 상관관계가 있었다 $(p<0.001)$ (Table 3).

역류증상지수를 각 항목으로 나눠서 분석해 보았을 때, 우 울증은 역류증상지수 9개 모든 항목에서 통계학적으로 의미 있는 상관관계가 있었고, 불안증은 후비루를 제외한 8개 항 목에서, 신체화장애는 연하곤란, 앙와위 기침, 숨막힘, 만성기 침, 속쓰림 등 5개 항목에서 통계학적으로 유의한 연관관계를 보였다.

그러나 역류소견점수는 우울증 $(p=0.183)$, 불안증 $(p=0.306)$, 신체화장애 $(p=0.833)$ 와는 유의한 상관관계를 보이지 않았 다. 다변량 분석을 통해 역류소견점수 항목과 우울증, 불안 증, 신체화장애의 관련성을 살펴본 결과, 우울증은 가슴쓰림 [odds ratio(OR): 1.241, 95\% confidence interval(CI): 1.003-

Table 2. 역류증상지수(reflux symptom index)

\begin{tabular}{|c|c|c|c|c|c|c|}
\hline \multirow{2}{*}{$\frac{\text { 최근 한 달간 환자분께 다음의 증상들이 얼마나 문제가 되었습니까? 그 정도에 동그라미 해 주세요. }}{\text { 1. 쉰 목소리가 난다(거칠거나, 고르지 않은 목소리가 난다, 목소리에 문제가 있다). }}$} & \multicolumn{6}{|c|}{$\begin{array}{c}0=\text { 전혀 문제 되지 않았다. } \\
5=\text { 아주 심하여서 심각한 지장을 준다. }\end{array}$} \\
\hline & 0 & 1 & 2 & 3 & 4 & 5 \\
\hline 2. 목청을 가다듬는다(하루에 네 번 이상 목청을 가다듬는다, 헛기침을 한다). & 0 & 1 & 2 & 3 & 4 & 5 \\
\hline 3. 후비루가 있다(코에서 목구멍으로 점액이나 분비물이 넘어간다). & 0 & 1 & 2 & 3 & 4 & 5 \\
\hline 4. 음식물을 삼키기 어렵다. & 0 & 1 & 2 & 3 & 4 & 5 \\
\hline 5. 식사 후나 누우면 기침이 나온다. & 0 & 1 & 2 & 3 & 4 & 5 \\
\hline 6. 숨쉬기 힘들거나 가끔 사레가 든다. & 0 & 1 & 2 & 3 & 4 & 5 \\
\hline 7. 성가시거나 문제가 되는 기침이 난다. & 0 & 1 & 2 & 3 & 4 & 5 \\
\hline 8. 목구멍에 이물감을 느낀다(목구멍에 덩어리가 걸려있는 느낌이 든다). & 0 & 1 & 2 & 3 & 4 & 5 \\
\hline 9. 가슴이 쓰리거나, 가슴이 아프거나, 소화가 안 되거나, 위산이 넘어오는 것을 느낀다. & 0 & 1 & 2 & 3 & 4 & 5 \\
\hline
\end{tabular}

Adapted from Belafsky, et al. J Voice 2002;16(2):274-76)

Table 3. Baseline symptom characteristics $(n=231)$

\begin{tabular}{|c|c|c|c|c|c|c|c|c|c|}
\hline \multirow{2}{*}{ Parameter } & \multicolumn{3}{|c|}{ Depression } & \multicolumn{3}{|c|}{ Anxiety } & \multicolumn{3}{|c|}{ Somatization } \\
\hline & Yes $(n=90)$ & No $(n=141)$ & p-value & Yes $(n=58)$ & No $(n=173)$ & p-value & Yes $(n=45)$ & No $(n=186)$ & p-value \\
\hline Age (years) & $54.2 \pm 10.6$ & $55.0 \pm 10.1$ & 0.546 & $54.9 \pm 12.2$ & $54.6 \pm 9.5$ & 0.862 & $53.1 \pm 10.1$ & $55.0 \pm 10.3$ & 0.264 \\
\hline Gender (\%) & & & 0.081 & & & 0.103 & & & $0.004^{*}$ \\
\hline Male & 30.1 & 69.9 & & 17.8 & 82.2 & & 8.2 & 91.8 & \\
\hline Female & 43.0 & 57.0 & & 28.5 & 71.5 & & 24.7 & 75.3 & \\
\hline Total RSI & $18.4 \pm 8.3$ & $12.3 \pm 7.0$ & $<0.001^{*}$ & $19.5 \pm 8.5$ & $13.0 \pm 7.3$ & $<0.001^{*}$ & $19.2 \pm 9.1$ & $13.6 \pm 7.5$ & $<0.001^{*}$ \\
\hline Hoarseness & $2.1 \pm 1.6$ & $1.5 \pm 1.4$ & $0.002^{*}$ & $2.1 \pm 1.8$ & $1.6 \pm 1.4$ & $0.044^{*}$ & $2.0 \pm 1.6$ & $1.7 \pm 1.5$ & 0.310 \\
\hline Throat clearing & $3.0 \pm 1.6$ & $2.2 \pm 1.6$ & $0.001 *$ & $3.1 \pm 1.7$ & $2.3 \pm 1.6$ & $0.004^{*}$ & $2.8 \pm 1.7$ & $2.4 \pm 1.7$ & 0.163 \\
\hline PND & $2.1 \pm 1.7$ & $1.6 \pm 1.5$ & $0.017^{*}$ & $2.1 \pm 1.8$ & $1.6 \pm 1.5$ & 0.083 & $2.1 \pm 1.8$ & $1.7 \pm 1.6$ & 0.144 \\
\hline Swallowing difficulty & $1.2 \pm 1.5$ & $0.7 \pm 1.2$ & $0.006^{*}$ & $1.5 \pm 1.6$ & $0.7 \pm 1.1$ & $0.001^{*}$ & $1.4 \pm 1.5$ & $0.8 \pm 1.3$ & $0.022 *$ \\
\hline Coughing when supine & $1.5 \pm 1.5$ & $0.8 \pm 1.1$ & $<0.001^{*}$ & $1.7 \pm 1.6$ & $0.8 \pm 1.1$ & $<0.001^{*}$ & $1.7 \pm 1.5$ & $0.9 \pm 1.2$ & $0.001^{*}$ \\
\hline Choking & $1.4 \pm 1.4$ & $0.7 \pm 1.0$ & $<0.001^{*}$ & $1.8 \pm 1.4$ & $0.7 \pm 1.0$ & $<0.001^{*}$ & $1.7 \pm 1.3$ & $0.8 \pm 1.1$ & $<0.001^{*}$ \\
\hline Chronic cough & $1.3 \pm 1.6$ & $0.8 \pm 1.2$ & $0.006^{*}$ & $1.4 \pm 1.6$ & $0.8 \pm 1.2$ & $0.009^{*}$ & $1.5 \pm 1.6$ & $0.8 \pm 1.3$ & $0.015^{*}$ \\
\hline Globus & $3.3 \pm 1.7$ & $2.5 \pm 1.7$ & $0.001 *$ & $3.3 \pm 1.8$ & $2.6 \pm 1.7$ & $0.011^{*}$ & $3.1 \pm 1.9$ & $2.7 \pm 1.7$ & 0.146 \\
\hline Heartburn & $2.6 \pm 1.7$ & $1.6 \pm 1.5$ & $<0.001^{*}$ & $2.6 \pm 1.7$ & $1.8 \pm 1.5$ & $<0.001^{*}$ & $2.8 \pm 1.4$ & $1.8 \pm 1.6$ & $<0.001^{*}$ \\
\hline Total RFS & $7.3 \pm 2.5$ & $6.9 \pm 2.2$ & 0.183 & $7.3 \pm 2.3$ & $6.9 \pm 2.3$ & 0.306 & $7.0 \pm 2.3$ & $7.0 \pm 2.4$ & 0.833 \\
\hline
\end{tabular}

*significant at $p<0.05$. RSI: reflux symptom index, PND: post nasal dripping, RFS: reflux finding score 
Reflux Symptom Index and Psychiatric Problems I Park IJ, et al.

Table 4. Adjusted OR and $95 \%$ Cls for psychiatric disorder according to the reflux symptom index

\begin{tabular}{|c|c|c|c|c|c|c|c|c|c|}
\hline \multirow{2}{*}{ Parameter } & \multicolumn{3}{|c|}{ Depression } & \multicolumn{3}{|c|}{ Anxiety } & \multicolumn{3}{|c|}{ Somatization } \\
\hline & OR & $95 \% \mathrm{Cl}$ & $p$-value & OR & $95 \% \mathrm{Cl}$ & $p$-value & OR & $95 \% \mathrm{Cl}$ & $p$-value \\
\hline Hoarseness & 1.174 & $0.961-1.435$ & 0.117 & 1.061 & $0.845-1.333$ & 0.61 & 0.957 & $0.745-1.230$ & 0.733 \\
\hline Throat clearing & 1.062 & $0.828-1.363$ & 0.634 & 1.103 & $0.821-1.481$ & 0.514 & 0.862 & $0.627-1.185$ & 0.360 \\
\hline PND & 0.931 & $0.734-1.180$ & 0.553 & 0.868 & $0.660-1.142$ & 0.313 & 0.989 & $0.737-1.326$ & 0.939 \\
\hline Swallowing difficulty & 1.088 & $0.854-1.386$ & 0.494 & 1.246 & $0.963-1.612$ & 0.095 & 1.041 & $0.786-1.378$ & 0.780 \\
\hline Coughing when supine & 1.201 & $0.896-1.611$ & 0.220 & 1.202 & $0.868-1.665$ & 0.269 & 1.227 & $0.871-1.729$ & 0.242 \\
\hline Choking & 1.275 & $0.974-1.670$ & 0.077 & 1.747 & $1.297-2.352$ & $<0.001^{*}$ & 1.707 & $1.248-2.336$ & $0.001^{*}$ \\
\hline Chronic cough & 1.035 & $0.793-1.351$ & 0.801 & 0.998 & $0.736-1.352$ & 0.987 & 1.071 & $0.779-1.473$ & 0.673 \\
\hline Globus & 1.117 & $0.913-1.367$ & 0.281 & 1.056 & $0.834-1.336$ & 0.652 & 0.983 & $0.767-1.260$ & 0.894 \\
\hline Heartburn & 1.241 & $1.003-1.537$ & $0.047^{*}$ & 1.119 & $0.873-1.435$ & 0.375 & 1.296 & $0.990-1.698$ & 0.059 \\
\hline
\end{tabular}

*significant at $p<0.05$. OR: odds ratio, $\mathrm{Cl}$ : confidence interval, PND: post nasal dripping

$1.537, p=0.047$, 불안증(OR: $1.747,95 \% \mathrm{CI}: 1.297-2.352, p<$ 0.001)과 신체화장애(OR: $1.707,95 \%$ CI: $1.248-2.336, p=0.001)$ 에서는 숨막힘 만이 통계학적으로 유의하게 나왔다(Table 4).

\section{고 찰}

이비인후과 외래에서는 인후두 역류 관련 증상들을 흔히 볼 수가 있다. Kamani 등 ${ }^{19)}$ 은 영국 전체인구 $34.4 \%$ 에 달하 는 수가 인후두 역류질환 증상을 나타낸다고 추정하였다. 인 후두 역류질환은 상부 기관 식도의 모든 구조물에 영향을 끼치므로 인두이물감, 만성 인두 청소행위, 만성 기침, 목소 리의 변화, 발성 장애, 위산역류, 과다한 인후 점액, 후비루, 연하곤란, 흉골하 작열감 등 여러 이비인후과적 증상을 나타 낸다. 인후두 역류질환의 가장 흔한 후두내시경 진찰소견은 후두의 부종과 발적 소견이다. 다양한 연구들에서 무증상의 건강한 사람들에게서도 후두의 비정상 소견이 발견된다는 것을 밝힌 바 있다. ${ }^{320)}$ 이와 반대로, 만성적인 헛기침, 인후두 이물감 등의 증상을 보이는 환자들의 많은 경우에서 후두경 검사 상 특별한 비정상 소견을 보이지 않기도 한다. 이렇게 증상과 진찰소견이 불일치하는 경우가 많고, 이러한 증상의 발생 원인이 불확실하기 때문에 인후두 역류증상과 정신적 인 문제의 연관성을 가설로 생각해 볼 수 있었다.

이전의 많은 연구들에서 인후두 역류질환과 심리적 인자 들, 정신적 질환과의 연관성을 연구해왔다. 최근 한 코호트 연구에서 대조군에 비해 인후두 역류질환군의 $1 / 3$ 에 해당하 는 환자들이 불안증이 있거나 유의하게 사회성이 떨어지는 것을 호소한다는 것을 밝힌 바 있다. ${ }^{21)}$ 인후두 이물감 증세 를 호소하는 환자들에게 항우울제인 amitriptyline과 양자 펌프 억제제인 pantoprazole을 투여한 무작위 전향적 연구 에 따르면 amitriptyline을 복용한 환자들에게서 인후두 통 증이나 수면의 질이 호전되는 것을 확인하여 인후두 이물감 환자에게 항우울제를 투여하자고 보고하였다. ${ }^{22)}$ 반대로 다른
연구들에서는 인후두 역류질환 환자들이 어떠한 심리적 고통 도 보이지 않았다고 하였다. ${ }^{23,24)}$ Mesallam 등 ${ }^{24)}$ 은 인후두 역 류질환 환자들의 심리적 배경이 역류 관련 증상을 자각하는 데 영향을 미치지 않는다고 하였다.

인후두 역류질환의 증상들에 대해서도 정신적인 문제와 연관 지으려는 연구들이 보고되었으며, 그중 가장 대표적 증 상인 인후두 이물감은 항우울증 치료에 반응이 좋아서 정신 적 혹은 신경증적인 원인이 인후두 이물감을 유발하는 것으 로 유추할 수 있었다. ${ }^{8)}$ Park 등 ${ }^{25)}$ 은 이물감 증상을 호소하는 환자들이 인후두 역류질환 보다는 신체화장애가 있는 경향 이 있다고 했으며 Barofsky와 Fontaine ${ }^{26)}$ 은 삼킴장애를 호 소하는 환자들에서 영상학적인 평가를 비롯하여 인두의 기능 은 정상이지만, 심리적인 특성(대인 민감성, 우울증, 불안증 등)을 나타내는 환자군이 있다는 것을 보고하였다. 또한 Son 등 $^{14)}$ 은 인후두부 이물감의 대부분을 위식도 역류와 식도운 동질환으로 설명하려는 최근의 시도는 재고되어야 하며, 인 후두부 이물감을 호소하는 환자에서 신체화경향, 우울증, 정 서불안, 건강염려증 등의 심인성의 요인을 무시할 수 없으며, 특히 우울증은 강한 연관성이 있을 것으로 보여, 환자 진료 시 참고하여야 한다고 하였다. 인후두 이물감 및 삼킴장애는 앞서 언급하였듯이 모두 역류증상지수의 지표 중 하나이다. 본 연구결과에서처럼 역류증상지수의 각 항목들이 정신적인 문제와 연관이 있으므로, 높은 역류증상지수를 보이는 환자 가 쉽게 호전되지 않는 인후두역류증상 들을 보인다면, 항우 울증 치료를 시도해보거나 정신과적인 평가를 고려하는 것 이 도움이 된다고 생각할 수 있겠다.

또한, 역류증상지수 중 가슴쓰림은 위식도 역류질환(gastroesophageal reflux disease)의 대표적 증상 중 하나인데, 위 식도 역류질환과 정신과적 문제의 연관성을 연구한 논문들 이 다수 보고되었다. El-Serag 등 ${ }^{27)}$ 의 메타분석에서는 약물 치료를 함에도 지속되는 위식도 역류질환의 증상은 육체적, 정신적 건강과 연관이 있다고 했으며, van der Velden 등르는 
위산억제 치료에도 반응하지 않는 위식도 역류질환 증상들 은 불안증, 우울증과 각각 $2.8,3.2$ 의 상관관계비가 있다고 보고하였다. 본 연구결과에서 가슴쓰림 증상은 역류증상지수 지표들 중 유일하게 우울증과 유의한 연관관계를 보였기 때문 에 마찬가지로 약물치료를 함에도 지속되는 가슴쓰림 증상 을 호소하는 환자가 있을 때, 항우울증 치료를 시도하거나 우울증에 관한 정신과적인 평가를 하는 것이 도움이 된다고 생각 할 수 있다. 이번 연구의 제한점으로는 첫째, 연구 코호트 가 작았고 표준 편차가 컸다. 둘째, 환자에게 동반된 다른 정 신 질환을 고려하지 않았다. 셋째, 이전 다른 연구에서처럼 우울증에 대한 진단을 위해 다양한 검사를 시행하지 못하였 다. 추후 인후두 역류질환과 정신과적 질환의 상관관계에 대 한 무작위 전향적 연구가 필요할 것으로 사료된다.

결론적으로, 인후두 역류질환 환자들에서 역류소견점수 는 우울증, 신체화장애, 불안증과 유의한 상관관계를 보이며 이 중 가슴쓰림은 우울증과 유의한 연관이 있고 숨막힘은 불안증 및 신체화장애와 관련이 있음을 알 수 있었다. 인후 두 역류질환의 이러한 증상을 호소하는 환자들의 중 원인질 환으로 정신과적 문제들을 염두에 두어야 하며 환자 진료시 참고하여야 할 것으로 사료된다.

\section{REFERENCES}

1) Vaezi MF, Hicks DM, Abelson TI, Richter JE. Laryngeal signs and symptoms and gastroesophageal reflux disease (GERD): a critical assessment of cause and effect association. Clin Gastroenterol Hepatol 2003;1(5):333-44.

2) Kim YM. The management of laryngopharyngeal reflux disease. Korean J Otorhinolaryngol-Head Neck Surg 2002;45(9):835-8.

3) Hicks DM, Ours TM, Abelson TI, Vaezi MF, Richter JE. The prevalence of hypopharynx findings associated with gastroesophageal reflux in normal volunteers. J Voice 2002;16(4):564-79.

4) Pratt LW, Tobin WH, Gallagher RA. Globus hystericus -- office evaluation by phychological testing with the MMPI. Laryngoscope 1976;86(10):1540-51.

5) Koufman JA, Amin MR, Panetti M. Prevalence of reflux in 113 consecutive patients with laryngeal and voice disorders. Otolaryngol Head Neck Surg 2000;123(4):385-8.

6) Belafsky PC, Postma GN, Koufman JA. Validity and reliability of the reflux symptom index (RSI). J Voice 2002;16(2):274-7.

7) Belafsky PC, Postma GN, Koufman JA. The validity and reliability of the reflux finding score (RFS). Laryngoscope 2001;111(8):1313-7.

8) Mirza N, Ruiz C, Baum ED, Staab JP. The prevalence of major psychiatric pathologies in patients with voice disorders. Ear Nose Throat J 2003;82(10):808-14.

9) Bhatia MS, Chandra R, Vaid L. Psychogenic cough: a profile of 32 cases. Int J Psychiatry Med 2002;32(4):353-60.

10) Cybulska EM. Globus hystericus--a somatic symptom of depression?
The role of electroconvulsive therapy and antidepressants. Psychosom Med 1997;59(1):67-9.

11) Carney IK, Gibson PG, Murree-Allen K, Saltos N, Olson LG, Hensley MJ. A systematic evaluation of mechanisms in chronic cough. Am J Respir Crit Care Med 1997;156(1):211-6.

12) Färkkilä MA, Ertama L, Katila H, Kuusi K, Paavolainen M, Varis $\mathrm{K}$. Globus pharyngis, commonly associated with esophageal motility disorders. Am J of Gastroenterol 1994;89(4):503-8.

13) Yoo CS, Kim DS, Lee SK, Lee BD, Chang HS, Kang JW. A study for causative diseases of globus pharyngeus patients who have no pathologic conditions in laryngopharynx. Korean J OtorhinolaryngolHead Neck Surg 1998;41(12):1573-8.

14) Son YI, Kwon JK, Rhee PL, Lee HY, Ryu BH, Kim JH. Importance of psychological factors and organic factors in globus pharyngeus. Korean J Otorhinolaryngol-Head Neck Surg 1998;41(3):381-4.

15) Joo YH, Song YS, Pae CU. Relationship between depression and laryngopharyngeal reflux. Psychiatry Investig 2017;14(2):226-9.

16) Han C, Jo SA, Kwak JH, Pae CU, Steffens D, Jo I, et al. Validation of the Patient Health Questionnaire-9 Korean version in the elderly population: the Ansan Geriatric study. Compr Psychiatry 2008;49(2): 218-23.

17) Han C, Pae CU, Patkar AA, Masand PS, Kim KW, Joe SH, et al. Psychometric properties of the Patient Health Questionnaire-15 (PHQ-15) for measuring the somatic symptoms of psychiatric outpatients. Psychosomatics 2009;50(6):580-5.

18) Spitzer RL, Kroenke K, Williams JB, Löwe B. A brief measure for assessing generalized anxiety disorder: the GAD-7. Arch Intern Med 2006;166(10):1092-7

19) Kamani T, Penney S, Mitra I, Pothula V. The prevalence of laryngopharyngeal reflux in the English population. Eur Arch Otorhinolaryngol 2012;269(10):2219-25.

20) Milstein CF, Charbel S, Hicks DM, Abelson TI, Richter JE, Vaezi MF. Prevalence of laryngeal irritation signs associated with reflux in asymptomatic volunteers: impact of endoscopic technique (rigid vs. flexible laryngoscope). Laryngoscope 2005;115(12):2256-61.

21) Siupsinskiene N, Adamonis K, Toohill RJ. Quality of life in laryngopharyngeal reflux patients. Laryngoscope 2007;117(3):480-4.

22) You LQ, Liu J, Jia L, Jiang SM, Wang GQ. Effect of low-dose amitriptyline on globus pharyngeus and its side effects. World J Gastroenterol 2013;19(42):7455-60.

23) Shin KS, Tae K, Jeong JH, Jeong SW, Kim KR, Park CW, et al. The role of psychological distress in laryngopharyngeal reflux patients: a prospective questionnaire study. Clin Otolaryngol 2010;35(1):25-30.

24) Mesallam TA, Shoeib RM, Farahat M, Kaddah FA, Malki KH. Studying the psychological profile of patients with laryngopharyngeal reflux. Folia Phoniatr Logop 2015;67(2):51-6.

25) Park KH, Choi SM, Kwon SU, Yoon SW, Kim SU. Diagnosis of laryngopharyngeal reflux among globus patients. Otolaryngol Head Neck Surg 2006;134(1):81-5.

26) Barofsky I, Fontaine KR. Do psychogenic dysphagia patients have an eating disorder? Dysphagia 1998;13(1):24-7.

27) El-Serag H, Becher A, Jones R. Systematic review: persistent reflux symptoms on proton pump inhibitor therapy in primary care and community studies. Aliment Pharmacol Ther 2010;32(6):720-37.

28) van der Velden AW, de Wit NJ, Quartero AO, Grobbee DE, Numans ME. Maintenance treatment for GERD: residual symptoms are associated with psychological distress. Digestion 2008;77(3-4):207-13. 